\title{
Expression of miR-720 is correlated with DNMT3 in Oral squamous cell carcinomas
}

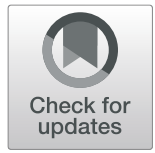

Andrew Graves ${ }^{1}$, Sukhdeep Sandhu ${ }^{1}$ and Karl Kingsley ${ }^{2^{*}}$ (D)

\begin{abstract}
Background: Many factors are involved with cellular differentiation and pluripotency, such as long non-coding and microRNAs (miRNA). miR-720 has been demonstrated to affect development, differentiation and pluripotency in dental pulp stem cells but has also been linked to many cancers (renal, prostate, skin, colorectal, breast, cervical and esophageal) through shared pathways including DNA methyltransferase family members (DNMT)3a and DNMT3b, which are highly upregulated in many oral cancers. However, little is known about the expression (or function, if expressed) of miR-720 in oral cancers. Based upon this lack of information, the primary objective of this project was to evaluate the expression of miR-720 among oral squamous cell carcinomas.

Methods: RNA was extracted from commercially available oral cancer cell lines (SCC4, SCC9, SCC15, SCC25 and CAL27). This was subsequently screened for DNMT1, DNMT-3a, DNMT-3b, and miR-720 expression using highspecificity primers and polymerase chain reaction (RT-PCR). Proliferation assays were performed to determine the proliferation rate of each cell line.

Results: Variable expression of miR-720 was observed among the oral cancers. More specifically, expression was low or absent among SCC4 and SCC25 that correlated with relatively low expression of DNMT3a and DNMT3b mRNA expression. High expression was observed among CAL27, SCC15, and SCC9 cells that correlated with relatively higher levels of DNMT3a and DNMT3b. Pearson's correlation found an association between proliferation rate of each cell line and expression of miR-720 assessed by RT-PCR; $R=0.8488$.

Conclusions: Although much is known about miR-720 - no studies to date have examined expression among oral cancers and tumor cell lines. This study may be the first to examine miR-720 expression in normal and cancerous oral tissues. These results demonstrate that miR-720 can be found in the most rapidly proliferating cell lines and may also correlate with expression of DNMT3a and DNMT3b expression in these same cell lines.
\end{abstract}

Keywords: Oral cancer, microRNA (miRNA), miR-720, DNA methyltransferase (DNMT)

\section{Background}

Many factors are involved with cellular differentiation and pluripotency, including recently discovered modulators such as long non-coding and microRNAs (miRNA) [1-3]. MicroRNA expression is known to regulate protein and mRNA expression through a variety of mechanisms, including direct and indirect modulation of mRNA transcription through DNA-binding complexes and mediation

\footnotetext{
*Correspondence: karl.kingsley@unlv.edu

${ }^{2}$ Department of Biomedical Sciences, University of Nevada, Las Vegas -

School of Dental Medicine, 1001 Shadow Lane, Las Vegas, NV 89106, USA

Full list of author information is available at the end of the article
}

of mRNA translation through complex inhibitory sequence interactions [4-6]. Although much remains to be discovered, several important microRNAs have been identified that may be key regulators of gene expression relating specifically to human health and disease $[7,8]$.

One such microRNA, miR-720, has been linked to many cancers, including colorectal, breast, prostate, and cervical cancers [9-12]. Recently it was reported that miR-720 may influence dental pulp stem cell proliferation and differentiation through shared pathways including DNA methyltransferase family members DNMT3a and DNMT3b, which are also highly upregulated in

(c) The Author(s). 2020 Open Access This article is licensed under a Creative Commons Attribution 4.0 International License, which permits use, sharing, adaptation, distribution and reproduction in any medium or format, as long as you give appropriate credit to the original author(s) and the source, provide a link to the Creative Commons licence, and indicate if changes were made. The images or other third party material in this article are included in the article's Creative Commons licence, unless indicated otherwise in a credit line to the material. If material is not included in the article's Creative Commons licence and your intended use is not permitted by statutory regulation or exceeds the permitted use, you will need to obtain permission directly from the copyright holder. To view a copy of this licence, visit http://creativecommons.org/licenses/by/4.0/. 
many oral cancers [13-15]. The family of DNMT enzymes influence gene activity through methylation and epigenetic modifications and are known to play a significant role in the development and pathophysiology of many cancers [16-18].

However, little is known about the expression (or function, if expressed) of miR-720 in oral cancers. Based upon this lack of information, the primary objective of this project was to evaluate the expression of miR-720 among oral squamous cell carcinomas.

\section{Methods}

\section{Cell culture}

Several commercially available oral cancer cell lines were obtained from American Tissue Culture Collection (ATCC), including SCC4 (CRL-1624), SCC9 (CRL1629), SCC15 (CRL-1623), SCC25 (CRL-1628), and CAL27 (CRL-2095). Normal non-cancerous oral gingival cells HGF-1 (CRL-2014) and human fibroblasts Hs27 (CRL-1634) were also obtained. HGF-1, Hs27 and CAL27 cells were maintained in Dulbecco's Modified Eagle's Medium (DMEM) with the addition of $10 \%$ fetal bovine serum (FBS) and 1\% penicillin-streptomycin. SCC25, SCC15, SCC9 and SCC4 cells were maintained in a 1:1 mixture of Dulbecco's modified Eagle's medium and Ham's F12 medium containing $1.2 \mathrm{~g} / \mathrm{L}$ sodium bicarbonate, $2.5 \mathrm{mM} \mathrm{L}$-glutamine, $15 \mathrm{mM}$ 4-(2-hydroxyethyl)-1-piperazineethanesulfonic acid (HEPE) $\mathrm{S}$ and $0.5 \mathrm{mM}$ sodium pyruvate and supplemented with 400 $\mathrm{ng} / \mathrm{ml}$ hydrocortisone and $10 \%$ fetal bovine serum. All cell cultures were maintained in a humidified biosafety level-2 (BSL-2) tissue culture chamber.

\section{RNA isolation}

RNA was extracted from T25 flasks of each cell line at approximately $70 \%$ confluence using the TRIzol RNA isolation reagent (Fisher Scientific) and repeated in triplicate. In brief, supernatant was aspirated from each cell culture and $1 \mathrm{~mL}$ of TRIzol reagent was added to homogenize the cell monolayer in each flask for approximately 5 minutes at room temperature. Each sample was then transferred to a microcentrifuge tube and $0.2 \mathrm{~mL}$ of chloroform was added and mixed thoroughly prior to incubation for an additional 5 minutes. Each sample was then centrifuged at 12,000 x g or relative centrifugal force (RCF) for $15 \mathrm{~min}$ at $4{ }^{\circ} \mathrm{C}$.

Following centrifugation, the aqueous upper phase was transferred to a sterile microcentrifuge tube and mixed with an equal volume of isopropyl alcohol prior to incubation at room temperature. Samples were then centrifuged at 12,000 RCF to precipitate the nucleic acids. Supernatant was removed and the RNA pellet was washed with $75 \%$ ethanol and centrifuged again. Supernatant was removed and $100 \mathrm{uL}$ of RNA rehydration solution was added to each microcentrifuge tube and allowed to rehydrate.

\section{RNA analysis}

Quality and quantity of RNA from each sample $(n=3$ per sample) was determined using a NanoDrop 2000 spectrophotometer (Fisher Scientific). Purity of RNA was measured using the absorbance readings at A260 $\mathrm{nm}$ and A280 nm. RNA with an A260:A280 ratio higher than 1.65 is considered to be acceptable purity for polymerase chain reaction (PCR) screening, without significant protein contamination. Quantitative analysis was determined automatically by the NanoDrop 2000 using the measured absorbance value at A260 nm and BeerLambert's equation, which measures the attenuation of incident light reaching the detector after passing through the sample.

\section{PCR screening}

To quantify the expression of specific mRNA, RT-PCR was performed on total RNA using the.

ABgene Reverse-iT One-Step RT-PCR Kit (ReadyMix

Version) and a Mastercycler gradient.

thermocycler (Eppendorf: Hamburg, Germany) using the following primers for:

\section{Internal control}

Glyceraldehyde 3-phosphate dehydrogenase (GAPDH).

GAPDH forward, 5'-ATCTTCCAGGAGCGAGAT CC-3'; 20 nt, 55\% GC, Tm: $66^{\circ} \mathrm{C}$

GAPDH reverse, $5^{\prime}$-ACCACTGACACGTTGGCAGT3'; 20 nt, $55 \%$ GC, Tm: $70{ }^{\circ} \mathrm{C}$

DNMT1 forward, 5'-GGCTACCTGGCTAAAGTC AAGTCC-3'; 24 nt, 54\% GC, Tm: $69^{\circ} \mathrm{C}$

DNMT1 reverse, $5^{\prime}$-CAAAAAGGGTGTCACTGT CCCGAC-3'; 24 nt, 54\% GC, Tm: $70^{\circ} \mathrm{C}$

DNMT3a forward, 5' - GAAGCGGAGTGAACCCCA

AC-3'; 20 nt, $60 \%$ GC, Tm: $69^{\circ} \mathrm{C}$

DNMT3a reverse, $5^{\prime}$ - CCTTGGTCACACAGCAGCC3'; 19 nt, $63 \%$ GC, Tm: $69^{\circ} \mathrm{C}$

DNMT3b forward, 5'-GCCAGCCTCACGACAGGA AAC-3'; 21 nt, $62 \%$ GC, $\mathrm{Tm}: 71^{\circ} \mathrm{C}$

DNMT3b reverse, 5 '-GACTGGGGGTGAGGGAGC ATC-3'; 21 nt, $67 \%$ GC, Tm: $73^{\circ} \mathrm{C}$

miR-720 forward, 5'-GCGTGCTCTCGCTGGGG-3'; $17 \mathrm{nt}, 76 \% \mathrm{GC}, \mathrm{Tm}: 73^{\circ} \mathrm{C}$

miR-720 reverse: $5^{\prime}$ - GTGCAGGGTCCGAGGT-3'; $16 \mathrm{nt}, 69 \% \mathrm{GC}, \mathrm{Tm}: 68^{\circ} \mathrm{C}$

Reaction products were separated by gel electrophoresis using Reliant 4\% NuSieve ${ }^{\circ}$ 3:1 Plus Agarose gels (Lonza: Rockland, ME). Bands were visualized by UV illumination of ethidium-bromide-stained gels and captured using a Kodak Gel Logic 100 Imaging System and 1D Image Analysis Software (Eastman Kodak: Rochester, NY). Quantitation of RT-PCR band densitometry and relative mRNA expression levels were performed using Adobe Photoshop (San Jose, CA) imaging software, 
Image Analysis tools and were repeated in triplicate $(n=$ $3)$.

\section{Proliferation assays}

Cells were plated in 96-well tissue culture plates at a density of $1.2 \times 10^{5}$ cells $/ \mathrm{mL}$ and allowed to grow for 24 , 48 and $72 \mathrm{~h}$. Cells were subsequently fixed with $10 \%$ formalin and stained using Gentian violet. Absorbance readings for each plate were measured using a BioTek ELx808 microplate reader at $595 \mathrm{~nm}$ to approximate cell number and confluence.

Absorbance (optical density) measurements of cell growth using a microplate reader are among the most commonly techniques used to quantify and characterize proliferation of cells in culture. Previous studies have demonstrated that the absorbance reading of cells stained with Gentian violet at $595 \mathrm{~nm}$ are proportional to cell number (concentration of cells in a 96-well plate) [19-21].

\section{Statistical analysis}

Differences between continuous variables (absorbance readings) were calculated using parametric statistical analysis methods, including two-tailed Student's t-tests and an alpha level of 0.05 to determine significance. Averages for normal and oral cancer cell signal band intensity (SBI) were calculated using Microsoft Excel and differences in SBI were calculated using Analysis of Variance (ANOVA) and an alpha level of 0.05 to determine statistical significance, which is appropriate for the evaluation of multiple two-way t-tests of parametric data.

\section{Results}

Cultures of each cell line were successfully established (Fig. 1). Proliferation rates varied among each of the various cell lines, with the most rapidly dividing oral cancer cell line CAL27 achieving 90-95\% confluence within $48-72 \mathrm{~h}$ following a 1:2 cell passage. The slowest among the oral cancer cell lines was SCC4, which only achieved approximately $30-40 \%$ confluence after $48-72$ $\mathrm{h}$ following the 1:2 cell passage. However, the normal non-cancerous oral gingival cell line, HGF-1, took approximately $10-12$ days to achieve $70 \%$ confluence.

Total RNA was isolated from each cell line at 70\% confluence and repeated in triplicate (Table 1). Analysis of these data demonstrated that RNA was successfully extracted from each cell line, ranging from 639.4-887.0 $\mathrm{ng} / \mathrm{uL}$ (average $745.7 \mathrm{ng} / \mathrm{uL}+/-70.2$ ). In addition, the purity as measured by A260:A280 ratio of absorbances demonstrated that each sample was of sufficient quality for processing and screening using PCR, ranging from 1.71 to 1.88 (average $1.78+/-0.08$ ).

The RNA from each cell line was then used to screen for mRNA expression of differentiation markers DNMT1, DNMT3a and DNMT3b - as well as miR-720 (Fig. 2) and was repeated in triplicate $(n=3)$ for each cell line. These data revealed relatively robust expression of the differentiation marker DNMT1 only within the normal, non-

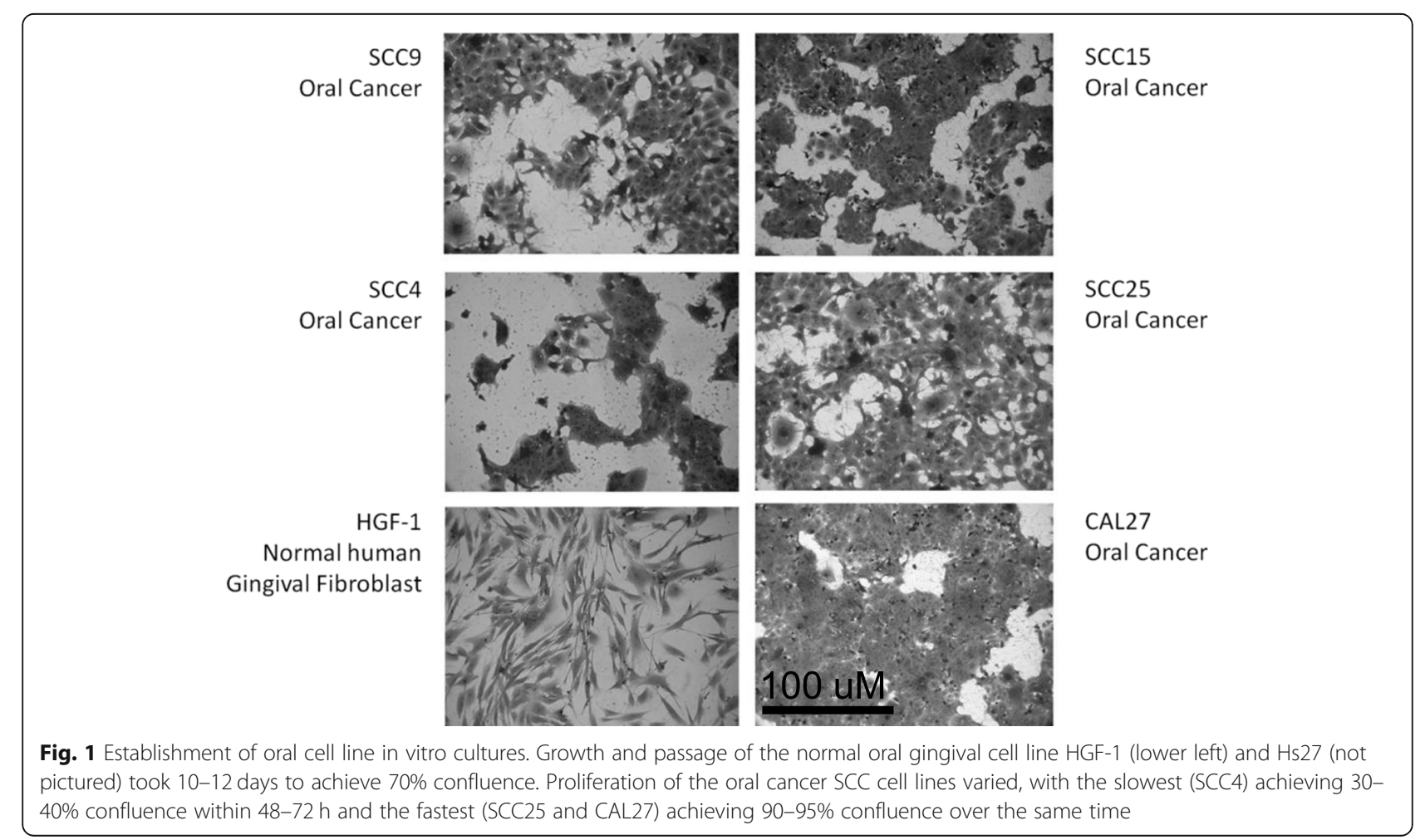


Table 1 Analysis of RNA

\begin{tabular}{lll}
\hline Cell line & RNA quantification $(\boldsymbol{n}=3)$ & RNA quality (A260:A280) \\
\hline Hs27 & $730.1 \mathrm{ng} / \mathrm{uL}+/-56.2(\mathrm{SD})$ & $1.71+/-0.08(\mathrm{SD})$ \\
HGF-1 & $716.3 \mathrm{ng} / \mathrm{uL}+/-83.1$ & $1.82+/-0.06$ \\
SCC4 & $639.4 \mathrm{ng} / \mathrm{uL}+/-51.3$ & $1.73+/-0.05$ \\
SCC9 & $713.2 \mathrm{ng} / \mathrm{uL}+/-73.1$ & $1.80+/-0.09$ \\
SCC15 & $760.3 \mathrm{ng} / \mathrm{uL}+/-62.0$ & $1.88+/-0.11$ \\
SCC25 & $887.0 \mathrm{ng} / \mathrm{uL}+/-88.2$ & $1.74+/-0.07$ \\
CAL27 & $773.6 \mathrm{ng} / \mathrm{uL}+/-77.4$ & $1.79+/-0.10$ \\
Averages & $745.7 \mathrm{ng} / \mathrm{uL}+/-70.2$ & $1.78+/-0.08$ \\
\hline
\end{tabular}

cancerous HGF-1 and Hs27 cells (Signal Band Intensity or SBI $128.2+/-4.1$ and $139.1+/-6.2$, respectively), with little to no observable mRNA expression among any of the oral cancer cell lines examined (SCC4 SBI: $6.5+/-1.2$, SCC9: $7.7+/-1.5$, SCC15: $13.2+/-3.2$, SCC25: $4.1+/-0.9$, CAL27: $6.6+/-1.1)$, which was statistically significant, $P=$ 0.01. In contrast, expression of DNMT3a and DNMT3b (markers of CpG-island methylator phenotype or CIMP) were not observed in either normal, non-cancerous cell line (HGF-1 SBI: $3.2+/-0.9$, Hs27: 1.4 +/- 0.3) but were highly expressed in all oral cancer cell lines examined (SCC4 SBI: 158.2 +/- 8.9, SCC9: $215.8+/-7.8$, SCC15: $309.5+/-12.3$, SCC25: $150.2+/-9.1$, CAL27: $204.0+/-15.1$ ), which was statistically significant, $P=0.003$. However, differential expression of miR-720 was observed among these cell lines with limited or low expression observed in both of the normal, non-cancerous cell lines (Hs27 SBI: $3.2+/-0.4$, HGF1: $4.9+/-0.5)$ as well as the slowest growing oral cancer cell line, SCC4 (SBI: $6.1+/-2.2$ ). Significantly higher levels of miR-720 expression were observed among the more rapidly dividing oral cancer cell lines (SCC9 SBI: $150.4+/-$ 10.1, SCC15: 223. $2+/-11.8$, SCC25: $101.0+/-9.2$ and CAL27: $145.2+/-8.6), P=0.008$.
To determine any correlation between the expression of miR-720 and growth rate of each cell, these data were plotted against one another and Pearson's correlation calculated (Fig. 3). These data demonstrate a strong linear relationship between miR-720 expression and proliferation rate of each cell line, regardless of the differentiation status, $\mathrm{R}=0.8488$. These data strongly suggest that miR-720 expression may be associated with growth rate in cell line and may therefore have an indirect or dietary effect on the pathways that influence and modulate these responses.

\section{Discussion}

Due to the lack of information regarding miR-720 in oral cancers, the primary objective of this project was to evaluate the expression among oral squamous cell carcinomas. These data revealed not only that miR-720 may be expressed widely among oral cancers but also that the levels of expression correlate with other phenotypic markers, such as proliferation and differentiation. This appears to support other studies of miR-720 that suggest this microRNA may have prognostic significance relating to proliferation rate, migration and invasion in colorectal, renal, and cervical cancers through pathways including Rab35 that may not be active in oral cancers [12, 22, 23].

However, these findings may conflict with other reports of miR-720 directly inhibiting other tumors, such as breast, through direct modulation of TWIST1 [24]. Expression (and overexpression) of TWIST has been documented in the development and phenotype of many oral cancers, which may suggest that other mediators of TWIST may be responsible for these observations [25, 26]. In fact, TWIST1 has been shown to be associated with many facets of epithelial-mesenchymal transitions in oral cancers and may therefore be regulated by

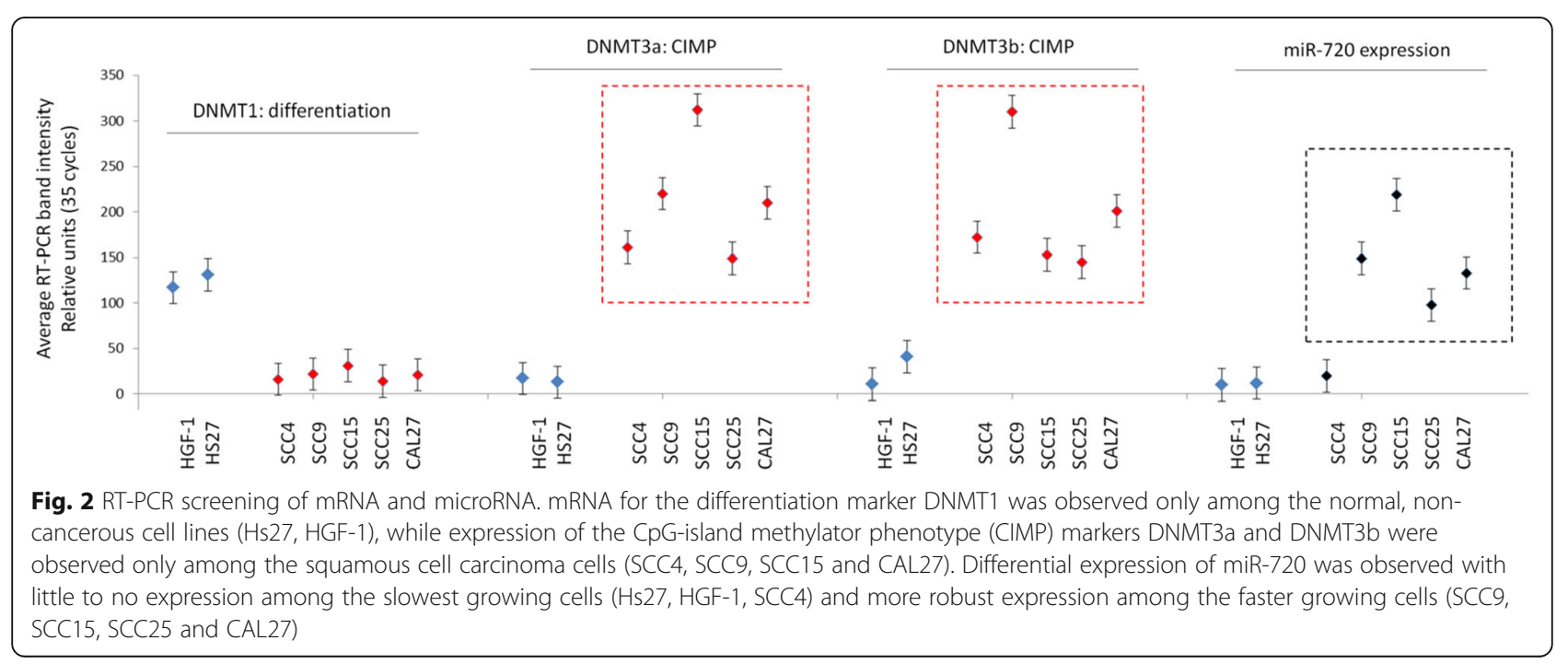




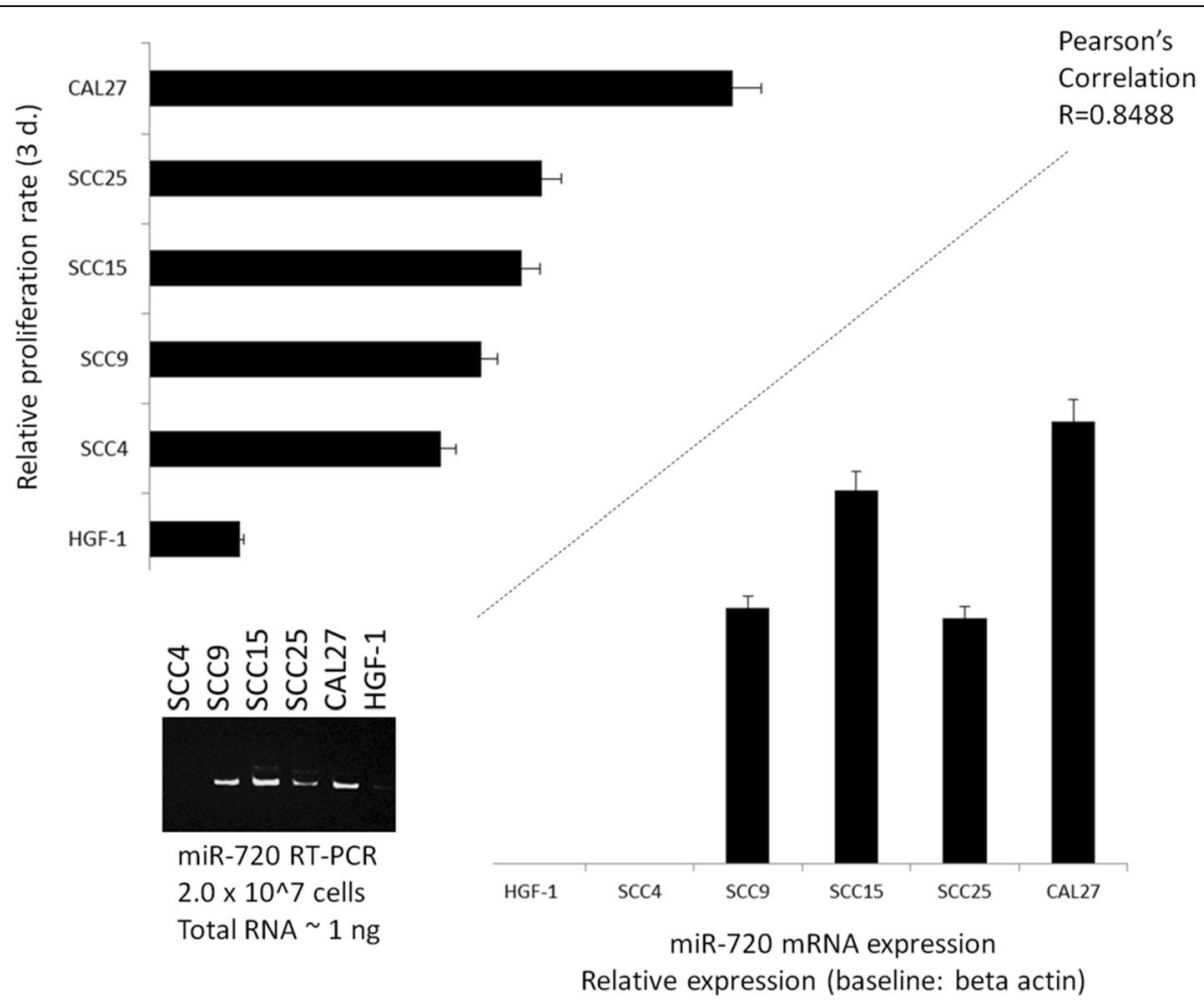

Fig. 3 Correlation between miR-720 expression and proliferation rate. Pearson's correlation demonstrated a strong, positive association between miR-720 and cellular growth, $R=0.8488$ using a standardized amount of total RNA (1.0 ng). This did not vary according to differentiation status (normal, cancerous) but was strongly correlated with proliferation rate only

multiple convergent pathways, including Let-7d and CCN3 that are also active in many oral cancers [27-29].

Despite these contradictions, many studies have demonstrated miR-720 is a downstream target of ERK activation that may, in turn, promote migratory and invasive phenotypes in other cancers [10,30-32]. This pathway is central to molecular carcinogenesis and pathogenesis of oral cancers and may represent one of the most important mechanisms of interactive modulation [30, 31]. This may also represent one of the first demonstrations of miR-720 activity with relation to DNMT3, although other microRNAs have recently been identified, including miR-29, miR-143 and miR-182 [33-35].

One potential regulatory mechanism may be through modulation of vasohibin-1 (VASH1) - a recently identified novel prognostic factor for head and neck squamous cell carcinomas [36]. VASH1 is an angiogenesis inhibitor active in normal tissues, which may be suppressed (directly or indirectly) in many cancers and tumor types including head and neck cancers [37]. Previous research identified miR-31 and miR-720 as direct modulators and inhibitors of VASH1 in endothelial cells, although no direct evidence of miR-720 regulation of VASH1 in cancers has yet been established [38].

Another potential mechanism of action that should be explored in future studies may be through an indirect relationship with $\mathrm{Sp} 3$, a previously identified transcription factor that directly modulates DNMT3 activity in many types of cancer [39]. TWIST1 has previously been demonstrated to interact with both $\mathrm{Sp} 1$ and $\mathrm{Sp} 3$ in mesenchymal cells [40]. As previous studies have noted miR-720 induction of TWIST1, this may represent a potential downstream indirect relationship between miR720 and TWIST1 with Sp3 and DNMT3 expression although more studies will be needed to evaluate these pathways.

\section{Conclusions}

Although much is known about miR-720 - no studies to date have examined expression among oral cancers and tumor cell lines. This study may be the first to examine miR-720 expression in normal and cancerous oral tissues. These results demonstrate that miR-720 can be found in the most rapidly proliferating cell lines and may also correlate with expression of DNMT3a and DNMT3b expression in these same cell lines.

\section{Abbreviations}

DNMT: DNA methyltransferase; SCC: Squamous cell carcinoma;

DMEM: Dulbecco's Modified Eagle's Medium; FBS: Fetal bovine serum; HEPE S: 4-(2-hydroxyethyl)-1-piperazineethanesulfonic acid; BSL-2: Biosafety level-2; PCR: Polymerase chain reaction 


\section{Acknowledgements}

The authors would like to thank the Office of Research at the UNLV School of Dental Medicine and the Graduate and Professional Student Association for their assistance with this project.

\section{Authors' contributions}

KK was responsible for the overall project design. AG and SS were responsible for data generation and analysis. All authors contributed to the writing of this manuscript. The authors read and approved the final manuscript.

\section{Funding}

No external funding was obtained for this study. The authors would like to acknowledge the Office of Research at the University of Nevada, Las Vegas for support of this project. Dr. Karl Kingsley is co-investigator on the National Institute of Health (NIH) grant R15DE028431 to J. Ebersole.

\section{Availability of data and materials}

All materials are commercially available and data will be made available upon request.

\section{Ethics approval and consent to participate}

Not applicable.

\section{Consent for publication}

Not applicable.

\section{Competing interests}

The authors declare that they have no competing interests.

\section{Author details}

'Department of Clinical Sciences, University of Nevada, Las Vegas - School of Dental Medicine, 1001 Shadow Lane, Las Vegas, NV 89106, USA. ²Department of Biomedical Sciences, University of Nevada, Las Vegas - School of Dental Medicine, 1001 Shadow Lane, Las Vegas, NV 89106, USA.

\section{Received: 20 May 2020 Accepted: 20 August 2020}

\section{Published online: 23 September 2020}

\section{References}

1. Mohr AM, Mott JL. Overview of microRNA biology. Semin Liver Dis. 2015; 35(1):3-11. https://doi.org/10.1055/s-0034-1397344 Epub 2015 Jan 29. Review. PMID: 25632930

2. Subramanian S, Steer CJ. Special Issue: MicroRNA Regulation in Health and Disease. Genes (Basel). 2019;10(6):E457. https://doi.org/10.3390/ genes10060457 PMID: 31208024.

3. Wu W. MicroRNA, noise, and gene expression regulation. Methods Mol Biol. 2018;1699:91-6. https://doi.org/10.1007/978-1-4939-7435-1 7 PMID: 29086371.

4. Ferro E, Enrico Bena C, Grigolon S, Bosia C. From Endogenous to Synthetic microRNA-Mediated Regulatory Circuits: An Overview. Cells. 2019;8(12): E1540. https://doi.org/10.3390/cells8121540 Review. PMID: 31795372

5. McCall MN, Kim MS, Adil M, Patil AH, Lu Y, Mitchell CJ, Leal-Rojas P, Xu J, Kumar M, Dawson VL, Dawson TM, Baras AS, Rosenberg AZ, Arking DE, Burns KH, Pandey A, Halushka MK. Toward the human cellular microRNAome. Genome Res. 2017;27(10):1769-81. https://doi.org/10.1101/ gr.222067.117 Epub 2017 Sep 6. PMID: 28877962.

6. Seyhan AA. A multiplexed miRNA and transgene expression platform for simultaneous repression and expression of protein coding sequences. Mol BioSyst. 2016;12(1):295-312. https://doi.org/10.1039/c5mb00506j PMID: 26617199.

7. Jonas S, Izaurralde E. Towards a molecular understanding of microRNAmediated gene silencing. Nat Rev Genet. 2015;16(7):421-33. https://doi.org/ 10.1038/nrg3965 Epub 2015 Jun 16. Review. PMID: 26077373.

8. Fischer SEJ. RNA interference and MicroRNA-mediated silencing. Curr Protoc Mol Biol. 2015;112:26.1.1-5. https://doi.org/10.1002/0471142727.mb2601s112 Review. PMID: 26423588

9. Nonaka MR, Miyake Y, Hata T, Kagawa Y, Kato T, Osawa H, Nishimura J, Ikenaga M, Murata K, Uemura, Okuzaki D, Takemasa I, Mizushima T, Yamamoto H, Doki Y, Mori M. Circulating miR-103 and miR-720 as novel serum biomarkers for patients with colorectal cancer. Int J Oncol. 2015;47(3):
1097-102. https://doi.org/10.3892/ijo.2015.3064 Epub 2015 Jun 26. PMID: 26134152.

10. Das SG, Romagnoli M, Mineva ND, Barillé-Nion S, Jézéquel P, Campone M, Sonenshein GE. miR-720 is a downstream target of an ADAM8-induced ERK signaling cascade that promotes the migratory and invasive phenotype of triple-negative breast cancer cells. Breast Cancer Res. 2016;18(1):40. https:// doi.org/10.1186/s13058-016-0699-z PMID: 27039296.

11. Pashaei E, Pashaei E, Ahmady M, Ozen M, Aydin N. Meta-analysis of miRNA expression profiles for prostate cancer recurrence following radical prostatectomy. PLoS One. 2017;12(6):e0179543. https://doi.org/10.1371/ journal.pone.0179543 eCollection 2017. PMID: 28651018.

12. Tang Y, Lin Y, Li C, Hu X, Liu Y, He M, Luo J, Sun G, Wang T, Li W, Guo M. MicroRNA-720 promotes in vitro cell migration by targeting Rab35 expression in cervical cancer cells. Cell Biosci. 2015;5:56. https://doi.org/10 1186/s13578-015-0047-5 eCollection 2015. PMID: 26413265.

13. Hara ES, Ono M, Eguchi T, Kubota S, Pham HT, Sonoyama W, Tajima S, Takigawa M, Calderwood SK, Kuboki T. miRNA-720 controls stem cell phenotype, proliferation and differentiation of human dental pulp cells. PLoS One. 2013:8(12):e83545 PMID: 24386225.

14. Gaillard SL, Zahurak M, Sharma A, Durham JN, Reiss KA, SartoriusMergenthaler S, Downs M, Anders NM, Ahuja N, Rudek MA, Azad N. A phase 1 trial of the oral DNA methyltransferase inhibitor CC-486 and the histone deacetylase inhibitor romidepsin in advanced solid tumors. Cancer. 2019;125(16):2837-45. https://doi.org/10.1002/cncr.32138 Epub 2019 Apr 23. PMID: 31012962

15. Supic G, Kozomara R, Zeljic K, Jovic N, Magic Z. Prognostic value of the DNMTs mRNA expression and genetic polymorphisms on the clinical outcome in oral cancer patients. Clin Oral Investig. 2017;21(1):173-82. https://doi.org/10.1007/ s00784-016-1772-9 Epub 2016 Mar 11. PMID: 26966018.

16. Lyko F. The DNA methyltransferase family: a versatile toolkit for epigenetic regulation. Nat Rev Genet. 2018;19(2):81-92. https://doi.org/10.1038/nrg. 2017.80 Epub 2017 Oct 16. Review. PMID: 29033456

17. Morgan AE, Davies TJ, Mc Auley MT. The role of DNA methylation in ageing and cancer. Proc Nutr Soc. 2018;77(4):412-22. https://doi.org/10.1017/ S0029665118000150 Epub 2018 Apr 30. Review. PMID: 29708096.

18. Pan Y, Liu G, Zhou F, Su B, Li Y. DNA methylation profiles in cancer diagnosis and therapeutics. Clin Exp Med. 2018;18(1):1-14. https://doi.org/ 10.1007/s10238-017-0467-0 Epub 2017 Jul 27. Review. PMID: 28752221.

19. Osafi J, Hejazi A, Stutz DD, Keiserman MA, Bergman CJ, Kingsley K. Differential effects of 1,25-dihydroxyvitamin $D_{3}$ on oral squamous cell carcinomas in vitro. J Diet Suppl. 2014;11(2):145-54. https://doi.org/10.3109/ 19390211.2013.859209.

20. Moody M, Le O, Rickert M, Manuele J, Chang S, Robinson G, Hajibandeh J, Silvaroli J, Keiserman MA, Bergman CJ, Kingsley K. Folic acid supplementation increases survival and modulates high risk HPV-induced phenotypes in oral squamous cell carcinoma cells and correlates with p53 mRNA transcriptional down-regulation. Cancer Cell Int. 2012;12:10. https:// doi.org/10.1186/1475-2867-12-10

21. Kingsley K, Truong K, Low E, Hill CK, Chokshi SB, Phipps D, West MA Keiserman MA, Bergman CJ. Soy protein extract (SPE) exhibits differential in vitro cell proliferation effects in oral cancer and normal cell lines. J Diet Suppl. 2011;8(2):169-88. https://doi.org/10.3109/19390211.2011.571656.

22. Wang $X$, Kuang $Y$, Shen $X$, Zhou H, Chen $Y$, Han $Y$, Yuan B, Zhou J, Zhao H, Zhi Q, Xue X. Evaluation of miR-720 prognostic significance in patients with colorectal cancer. Tumour Biol. 2015;36(2):719-27. https://doi.org/10.1007/ s13277-014-2697-z Epub 2014 Oct 7. PMID: 25286763.

23. Bhat NS, Colden M, Dar AA, Saini S, Arora P, Shahryari V, Yamamura S, Tanaka Y, Kato T, Majid S, Dahiya R. MicroRNA-720 regulates E-cadherin-aEcatenin complex and promotes renal cell carcinoma. Mol Cancer Ther. 2017; 16(12):2840-8. https://doi.org/10.1158/1535-7163.MCT-17-0400 Epub 2017 Aug 11. PMID: 28802251

24. Li LZ, Zhang CZ, Liu LL, Yi C, Lu SX, Zhou X, Zhang ZJ, Peng YH, Yang YZ, Yun JP. miR-720 inhibits tumor invasion and migration in breast cancer by targeting TWIST1. Carcinogenesis. 2014;35(2):469-78. https://doi.org/10. 1093/carcin/bgt330 Epub 2013 Oct 1. PMID: 24085799.

25. Seyedmaiidi M, Seifi S, Moslemi D, Mozaffari SF, Gholinia H, Zolfaghari Z. Immunohistochemical expression of TWIST in oral squamous cell carcinoma and its correlation with clinicopathologic factors. J Cancer Res Ther. 2018; 14(5):964-9. https://doi.org/10.4103/0973-1482.224350 PMID: 30197332.

26. de Freitas Silva BS, Yamamoto-Silva FP, Pontes HA. Pinto Júnior Ddos S. Ecadherin downregulation and twist overexpression since early stages of oral 
carcinogenesis. J Oral Pathol Med. 2014;43(2):125-31. https://doi.org/10. 1111/jop.12096 Epub 2013 Jun 15. PMID: 23772858.

27. Chen PC, Tai HC, Lin TH, Wang SW, Lin CY, Chao CC, Yu HJ, Tsai YC, Lai YW, Lin CW. Tang CH. CCN3 promotes epithelial-mesenchymal transition in prostate cancer via FAK/Akt/HIF-1a-induced twist expression. Oncotarget. 2017;8(43):74506-18. https://doi.org/10.18632/oncotarget.20171 eCollection 2017 Sep 26. PMID: 29088803.

28. Chang CJ, Hsu CC, Chang CH, Tsai LL, Chang YC, Lu SW, Yu CH, Huang HS, Wang JJ, Tsai CH, Chou MY, Yu CC, Hu FW. Let-7d functions as novel regulator of epithelial-mesenchymal transition and chemoresistant property in oral cancer. Oncol Rep. 2011;26(4):1003-10. https://doi.org/10.3892/or. 2011.1360 Epub 2011 Jun 27. PMID: 21725603.

29. Ohgawara T, Kubota S, Kawaki H, Kurio N, Abd El Kader T, Hoshijima M, Janune D, Shimo T, Perbal B, Sasaki A, Takigawa M. Association of the metastatic phenotype with CCN family members among breast and oral cancer cells. J Cell Commun Signal. 2011;5(4):291-9. https://doi.org/10.1007/ s12079-011-0133-3 Epub 2011 Apr 18. PMID: 21499980.

30. Hong G, Kuek V, Shi J, Zhou L, Han X, He W, Tickner J, Qiu H, Wei Q, Xu J. EGFL7: master regulator of cancer pathogenesis, angiogenesis and an emerging mediator of bone homeostasis. J Cell Physiol. 2018;233(11):852637. https://doi.org/10.1002/jcp.26792 Epub 2018 Jun 19. Review. PMID: 29923200.

31. Gollob JA, Wilhelm S, Carter C, Kelley SL. Role of Raf kinase in cancer: therapeutic potential of targeting the Raf/MEK/ERK signal transduction pathway. Semin Oncol. 2006;33(4):392-406 Review. PMID: 16890795.

32. Lu W, Lu T, Wei X. Downregulation of DNMT3a expression increases miR182-induced apoptosis of ovarian cancer through caspase-3 and caspase-9mediated apoptosis and DNA damage response. Oncol Rep. 2016;36(6): 3597-604. https://doi.org/10.3892/or.2016.5134 Epub 2016 Sep 28. PMID: 27748882.

33. Zhang HP, Wang YH, Cao CJ, Yang XM, Ma SC, Han XB, Yang XL, Yang AN, Tian J, Xu H, Zhang MH, Jiang YD. A regulatory circuit involving miR-143 and DNMT3a mediates vascular smooth muscle cell proliferation induced by homocysteine. Mol Med Rep. 2016;13(1):483-90. https://doi.org/10.3892/ mmr.2015.4558 Epub 2015 Nov 12. PMID: 26573388.

34. Cicchini C, de Nonno V, Battistelli C, Cozzolino AM, De Santis PM, Ciafrè SA, Brocker C, Gonzalez FJ, Amicone L, Tripodi M. Epigenetic control of EMT/ MET dynamics: HNF4a impacts DNMT3s through miRs-29. Biochim Biophys Acta. 2015;1849(8):919-29. https://doi.org/10.1016/j.bbagrm.2015.05.005 Epub 2015 May 21. PMID: 26003733.

35. Yang G, Song Y, Zhou X, Deng Y, Liu T, Weng G, Yu D, Pan S. DNA methyltransferase 3 , a target of microRNA-29c, contributes to neuronal proliferation by regulating the expression of brain-derived neurotrophic factor. Mol Med Rep. 2015;12(1):1435-42. https://doi.org/10.3892/mmr.2015. 3531 Epub 2015 Mar 23. PMID: 25815896.

36. Torii C, Hida Y, Shindoh M, Akiyama K, Ohga N, Maishi N, Ohiro Y, Ono M, Totsuka Y, Kitagawa Y, Tei K, Sato Y, Hida K. Vasohibin-1 as a Novel Prognostic Factor for Head and Neck Squamous Cell Carcinoma. Anticancer Res. 2017;37(3):1219-25. https://doi.org/10.21873/anticanres.11437.

37. Yamamoto M, Ozawa S, Ninomiya Y, Koyanagi K, Oguma J, Kazuno A, Hara H, Yatabe K, Kajiwara H, Nakamura N, Sato Y. Plasma vasohibin-1 and vasohibin-2 are useful biomarkers in patients with esophageal squamous cell carcinoma. Esophagus. 2020;17(3):289-97. https://doi.org/10.1007/ s10388-020-00719-8.

38. Wang HW, Huang TS, Lo HH, et al. Deficiency of the microRNA-31microRNA-720 pathway in the plasma and endothelial progenitor cells from patients with coronary artery disease. Arterioscler Thromb Vasc Biol. 2014; 34(4):857-69. https://doi.org/10.1161/ATVBAHA.113.303001.

39. Lin RK, Wang YC. Dysregulated transcriptional and post-translational control of DNA methyltransferases in cancer. Cell Biosci. 2014;4:46. Published 2014 Aug 19. https://doi.org/10.1186/2045-3701-4-46.

40. Ohkuma M, Funato N, Higashihori N, Murakami M, Ohyama K, Nakamura M. Unique CCT repeats mediate transcription of the TWIST1 gene in mesenchymal cell lines. Biochem Biophys Res Commun. 2007;352(4):925-31. https://doi.org/10.1016/j.bbrc.2006.11.114.

\section{Publisher's Note}

Springer Nature remains neutral with regard to jurisdictional claims in published maps and institutional affiliations.

\section{Ready to submit your research? Choose BMC and benefit from:}

- fast, convenient online submission

- thorough peer review by experienced researchers in your field

- rapid publication on acceptance

- support for research data, including large and complex data types

- gold Open Access which fosters wider collaboration and increased citations

- maximum visibility for your research: over $100 \mathrm{M}$ website views per year

At BMC, research is always in progress.

Learn more biomedcentral.com/submissions 